\title{
Evaluation of cytotoxicity and pH changes generated by various dental pulp capping materials an in vitro study
}

\author{
Elzbieta Luczaj-Cepowicz ${ }^{1}$, Grazyna Marczuk-Kolada', Malgorzata Pawinska ${ }^{2}$, \\ Marta Obidzinska ${ }^{1}$, Adam Holownia ${ }^{3}$ \\ ${ }^{1}$ Department of Pedodontics, Medical University of Bialystok, Poland \\ ${ }^{2}$ Department of Integrated Dentistry, Medical University of Bialystok, Poland \\ ${ }^{3}$ Department of Clinical Pharmacology, Medical University of Bialystok, Poland
}

\begin{abstract}
Introduction. Various materials are used in direct dental pulp capping method. Their biocompatibility and alkalizing abilities are of primary importance affecting therapeutic effects. The aim of this study was to evaluate and compare the cytotoxicity of various pulp-capping materials on human gingival fibroblasts and investigate the $\mathrm{pH}$ changes induced by these materials.

Material and methods. Human gingival fibroblasts were cultured with nine direct pulp materials using culture plate inserts. The cytotoxic effects were recorded by using an MTT-based colorimetric assay after 3 and $24 \mathrm{~h}$. In the second part of the experiment, the materials were inserted in dialysis tubes and transferred into plastic vials containing deionized water. The changes of the medium $\mathrm{pH}$ were measured after 3 and $24 \mathrm{~h}$.

Results. We showed differences in cell viability of gingival fibroblasts after varied time of exposition for the tested materials. Cell viability after $24 \mathrm{~h}$ increased for Dycal, Biopulp, and Calcipro, and decreased for Calcipulpe, Angelus, Angelus White, and ProRoot Regular. Cell viability for ProRoot and Life did not change. Non-setting calcium hydroxide preparations followed by the MTA group and setting calcium hydroxide materials produced the highest $\mathrm{pH}$. All the tested materials significantly increased $\mathrm{pH}(p<0.0001)$ at $24 \mathrm{~h}$.

Conclusions. Currently used pulp capping materials varied in their cytotoxicity relative to human gingival fibroblasts and their alkalizing capacities. Since most likely $\mathrm{pH}$ does not affect the viability of cultured cells, further investigations are required to determine physicochemical properties of these materials and the biological activity of the dental pulp. (Folia Histochemica et Cytobiologica 2017, Vol. 55, No. 2, 86-93)
\end{abstract}

Key words: gingival fibroblasts; cytotoxicity; dental pulp capping materials; $\mathrm{pH}$

\section{Introduction}

The main goal of conservative dentistry is to preserve pulp health in compromised teeth, thus reducing the need for root canal treatment and the potential for undesirable sequelae such as tooth loss. Contemporary used methods for this purpose are direct pulp

Correspondence address: E. Luczaj-Cepowicz, M.D. Department of Pedodontics, Medical University of Bialystok Waszyngtona 15a St., 15-297 Bialystok, Poland tel./fax: +48 857450961

e-mail: elzbieta.luczaj-cepowicz@umb.edu.pl capping and pulpotomy. A final goal of the application of capping materials is to stimulate the dentinogenic potential of the pulp cells $[1,2]$. The effectiveness of such therapy is mostly dependent on the location and type of injury, the state of tooth development, the capping material applied and the integrity of cavity restoration [3]. A number of materials have been used for this purpose, such as calcium hydroxide $(\mathrm{CH})$ and, more recently, mineral trioxide aggregate (MTA) $[4,5]$

Calcium hydroxide has advantageous properties such as alkaline $\mathrm{pH}$, stimulation of mineralization and low cytotoxicity [6]. However, clinical observations of the procedures with $\mathrm{CH}$ and hard-setting $\mathrm{CH}$ often 
showed failures due to the porosity of the produced dentinal bridge, poor adherence to the dentin and low sealing ability [6].

Hence, there have been recent attempts to develop more effective materials. One of these materials is mineral trioxide aggregate (MTA), which appears to have better effects and has proved more beneficial than previously used materials. It has been demonstrated that MTA had better sealing capability and led to less pulpal inflammation and more predictable dentin bridge formation than $\mathrm{CH}$ [5].

Biocompatibility of direct pulp capping materials is of prime importance since they will be in close contact with dental pulp for long periods of time [2]. The American Dental Association and International Standards Organization Committee have encouraged the use of ex vivo methods [7]. To determine cytotoxicity, various methods have been recommended, including MTT-based colorimetric assay. The method is a rapid and simple test which identifies only living cells what allows measuring cell cytotoxicity and proliferation $[8,9]$. Since the therapeutic effects of direct pulp capping materials are related to their alkalizing abilities, it is important to define the $\mathrm{pH}$ values of commercial products. Hydroxide ions act by stimulating alkaline phosphatase, which plays a key role in the mineralization of dentin and bone [10].

The aim of this study was to: 1) evaluate and compare the cytotoxicity of various pulp-capping materials on human gingival fibroblasts mimicking the clinical procedure, and 2) investigate the $\mathrm{pH}$ changes produced by these materials.

\section{Material and methods}

Cell cultures. Human gingival fibroblasts (adherent permanent cell line ATCC ${ }^{\circledR}$ CRL-2014HGF-1) (LGC Promochem, Warsaw, Poland) grew in Falcon flasks ( $75 \mathrm{~cm}^{2}$ growth area) in the DMEM (Dulbecco's Modified Eagles Medium) medium (Gibco, Warsaw, Poland) supplemented with $10 \%$ fetal bovine serum (FBS), $100 \mathrm{U} / \mathrm{mL}$ penicillin, $100 \mathrm{U} / \mathrm{mL}$ streptomycin (all from Gibco), at $37^{\circ} \mathrm{C}, 5 \% \mathrm{CO}_{2}$ and $95 \%$ humidity. When confluent growth was obtained, the cells were incubated with $0.25 \%$ trypsin solution with $0.53 \mathrm{mM}$ EDTA added. Then a medium with $10 \%$ FBS was added to inhibit enzyme activity. The cell suspension, diluted in a fresh medium, was inoculated in 24-well plates and incubated for $24 \mathrm{~h}$.

Preparation of capping material and cell treatment. The nine materials included in this study were: MTA-Angelus white (Angelus Ind. De Productos Odontologicos LTDA, Londrina-Parana, Brazil), MTA-Angelus (Angelus Ind. De Productos Odontologicos LTDA, Londrina-Parana, Brazil), ProRoot (Densply Tulsa Dental Specialities, Johnson City,
TN, USA), ProRoot Regular (Densply Tulsa Dental Specialities, Johnson City, USA), Biopulp (Chema-Elektromet, Rzeszów, Poland), Calcipro (lege artis Pharma GmbH + Co., Dettenhausen, Germany), Calcipulpe (Septodont, Saint Maur des Fosses, France), Dycal (Dentsply De Tray GmbH, Konstanz, Germany) and Life (Kerr Italia S.r.l., Salerno, Italy). The main components of each material are described in Table 1 . The materials were mixed directly before the test, according to the manufacturer's instructions under aseptic conditions, except for Calcipulpe which was packaged in a syringe with no preparation needed.

The prepared materials were applied into plastic rings of $5 \times 5 \mathrm{~mm}$ (inner diameter $\times$ height). The rings with the materials were placed in inserts (Nunc GmbH \& Co. KG, Wiesbaden, Germany) of a surface area of $0.47 \mathrm{~cm}^{2}$ and a pore diameter of $0.4 \mu \mathrm{m}$, which were located in 24-well culture plates (Nunc GmbH \& Co. KG) containing human gingival fibroblasts. Twelve samples were prepared for each material. The culture plates with cells and applied materials in a freshly mixed state were incubated at $37^{\circ} \mathrm{C}$, $5 \% \mathrm{CO}_{2}$ and $95 \%$ humidity for $3 \mathrm{~h}$ (six plates) and for $24 \mathrm{~h}$ (next six plates). Six wells with inserts without any material constituted the control both for the 3-hour as well as 24-hour experiment.

Cytotoxicity assay. The cytotoxicity of the studied materials was evaluated with the MTT test. It is an indirect method determining cell viability and proliferation on the basis of mitochondrial succinate dehydrogenase activity. In live cells, this enzyme reduces a yellow tetrazole salt, 3-(4,5-dimethyl-2-thiazolyl)-2,5-diphenyl-2H-tetrazolium bromide, to formazan precipitating as insoluble grey-purple crystals. The intensity of the solution color after dissolving the crystals, measured by spectrophotometer, is a measure of cell viability. For low cell survival, low enzymatic activity is found resulting in low content of purple formazan and lower optical density values [11].

After $3 \mathrm{~h}$ and $24 \mathrm{~h}$ of cell incubation with capping materials, the inserts with the materials were removed and $1 \mathrm{~mL}$ of medium containing 3-(4,5-Dimethyl-2-thiazolyl)-2,5-diphenyl-2H-tetrazolium bromide (MTT) was added to each well at a concentration of $0.5 \mathrm{mg} / \mathrm{mL}$, and the plates were incubated without light in the conditions described above for $3 \mathrm{~h}$. Afterwards, the fluid was aspirated from the culture and $1 \mathrm{~mL}$ of isopropanol acidified with hydrochloric acid was added. To dissolve the formazan crystals, the obtained solution was stirred for a short time. The optical density (OD) was measured with a double-beam absorption spectrophotometer, Lambda EZ 2001 (Perkin Elmer, Waltham, MA, USA), at the $560 \mathrm{~nm}$ wavelength. Cell viability was calculated using the following formula: [Mean OD of test group/Mean OD of control group] $\times 100 \%$.

The evaluation of cell viability was scored according to the method of da Silva et al. [12]. If cell viability exceeded 
Table 1. Composition of dental pulp capping materials as provided by the manufacturer

\begin{tabular}{|c|c|c|c|}
\hline Material & Composition & Manufacturer & Batch number \\
\hline Calcipulpe (CP) & $\begin{array}{l}\text { Calcium dihydroxide, barium sulfate, } \\
\text { carboxymethylcellulose, excipients }\end{array}$ & $\begin{array}{l}\text { Septodont, Saint Maur des Fosses, } \\
\text { France }\end{array}$ & 42698AE \\
\hline Calcipro (CR) & Calcium dihydroxide, barium sulfate & $\begin{array}{l}\text { lege artis Pharma GmbH }+ \text { Co., } \\
\text { Dettenhausen, Germany }\end{array}$ & 0940907 \\
\hline Biopulp (B) & $\begin{array}{l}\text { Calcium dihydroxide, dibasic calcium phosphate, } \\
\text { magnesium oxide, sodium chloride, anhydrous } \\
\text { calcium chloride, potassium chloride, anhydrous } \\
\text { sodium carbonate }\end{array}$ & Chema-Elektromet, Rzeszow, Poland & 090903 \\
\hline $\begin{array}{l}\text { ProRoot MTA Grey } \\
\text { (GPMTA) }\end{array}$ & $\begin{array}{l}\text { Tricalcium silicate, dicalcium silicate, tricalcium } \\
\text { aluminate, bismuth oxide, calcium sulfate } \\
\text { dihydrate, tetracalcium aluminoferrite }\end{array}$ & $\begin{array}{l}\text { Dentsply Tulsa Dental Specialities, } \\
\text { Dentsply International Inc., Johnson } \\
\text { City, USA }\end{array}$ & 12035624 \\
\hline $\begin{array}{l}\text { ProRoot MTA White } \\
\text { (WPMTA) }\end{array}$ & $\begin{array}{l}\text { Tricalcium silicate, dicalcium silicate, tricalcium } \\
\text { aluminate, bismuth oxide, calcium sulfate } \\
\text { dihydrate }\end{array}$ & $\begin{array}{l}\text { Dentsply Tulsa Dental Specialities, } \\
\text { Dentsply International Inc., Johnson } \\
\text { City, USA }\end{array}$ & 10003598 \\
\hline $\begin{array}{l}\text { MTA Angelus Grey } \\
\text { (GAMTA) }\end{array}$ & $\begin{array}{l}\text { Tricalcium silicate, dicalcium silicate, tricalcium } \\
\text { aluminate, bismuth oxide, calcium oxide, } \\
\text { tetracalcium aluminoferrite }\end{array}$ & $\begin{array}{l}\text { Angelus Industria de Produtos } \\
\text { Odontologicos LTDA, Londrina- } \\
\text {-Parana, Brasil }\end{array}$ & 12872 \\
\hline $\begin{array}{l}\text { MTA Angelus White } \\
\text { (WAMTA) }\end{array}$ & $\begin{array}{l}\text { Tricalcium silicate, dicalcium silicate, tricalcium } \\
\text { aluminate, bismuth oxide, calcium oxide }\end{array}$ & $\begin{array}{l}\text { Angelus Industria de Produtos } \\
\text { Odontologicos LTDA, Londrina- } \\
\text {-Parana, Brasil }\end{array}$ & 9874 \\
\hline Life (L) & $\begin{array}{l}\text { Base: calcium dihydroxide, } \mathrm{N} \text {-ethyl-o/p-toluene } \\
\text { sulfonamide, zinc oxide, calcium oxide } \\
\text { Catalyst: methyl salicylate, barium sulfate, } \\
\text { titanium dioxide, 2-2-dimethylpropany-1,3-diol }\end{array}$ & Kerr Italia S.r.l., Salerno, Italy & 3628677 \\
\hline Dycal (D) & $\begin{array}{l}\text { Base: } 1,3 \text {-butylene glycol disalicylate, zinc oxide, } \\
\text { calcium phosphate, calcium tungstate iron, oxide } \\
\text { pigments } \\
\text { Catalyst: calcium dihydroxide, N-ethyl-o/p-toluene } \\
\text { sulfonamide, zinc oxide, titanium dioxide, zinc } \\
\text { stearate, iron oxide pigments }\end{array}$ & $\begin{array}{l}\text { Dentsply DeTrey GmbH, Konstanz, } \\
\text { Germany }\end{array}$ & 070821 \\
\hline
\end{tabular}

$90 \%$, the material was deemed non-cytotoxic. For cell viability at the $60-90 \%$ range, the material was regarded as slightly cytotoxic. For cell viability at the 30-59\% range, the material was regarded as moderately cytotoxic. For cell viability below $30 \%$, the material was considered severely cytotoxic.

pH assay. All materials were prepared as mentioned above. Shortly thereafter, $0.1 \mathrm{~g}$ of each material was placed into dialysis tubes (Sigma-Aldrich Chemie, Steinheim, Germany) and transferred into separate plastic vials containing $20 \mathrm{~mL}$ of deionized water. A total of 6 samples were used for each material. The vials were hermetically sealed and kept in an incubator at $37^{\circ} \mathrm{C}$.

Before each measurement, the vials were shaken for $5 \mathrm{sec}$ to ensure uniform hydroxyl ion distribution. The $\mathrm{pH}$ values were recorded immediately after immersion (baseline) and after 3 and $24 \mathrm{~h}$ with a pH-meter (ISE 710A, Orion Research Inc., Boston, MA, USA), previously calibrated with solutions of known $\mathrm{pH}$ [13-15]. Each sample was measured twice and the mean value was recorded. The experiment was per- formed in static conditions (without changing the deionized water) [15]. The $\mathrm{pH}$ of the deionized water in which an empty tube without capping materials was immersed (control) was 6.9 at all study periods [16].

Statistical analysis. All statistical analyses were performed using the Statistica 8.0 (StatSoft, Cracow, Poland) software package. One-way analysis of variance, ANOVA, for independent samples was applied to compare cytotoxicity and $\mathrm{pH}$ of the materials at each time point. If the difference was significant, individual comparisons were performed using Tukey's multiple comparisons test. The level of significance was set at $p<0.05$.

\section{Results}

The cytotoxicity of the tested materials after 3 and $24 \mathrm{~h}$ of incubation is presented in Table 2 . After $3 \mathrm{~h}$ of incubation, Angelus White and ProRoot exhibited no cytotoxicity. ProRoot Regular, Calcipulpe, Life and Dycal demonstrated slight cytotoxicity, Angelus 
Table 2. Cytotoxic effects of dental pulp capping materials on human gingival fibroblasts

\begin{tabular}{|c|c|c|c|c|c|c|c|c|c|}
\hline \multirow[t]{3}{*}{ Material } & \multicolumn{4}{|c|}{ Survival rate \% (SD) } & & & & & \\
\hline & \multicolumn{4}{|c|}{ Time (h) } & & & & & \\
\hline & \multicolumn{2}{|c|}{3} & \multicolumn{2}{|c|}{24} & & & & & \\
\hline $\mathbf{C P}$ & \multicolumn{2}{|c|}{$86.28(2.23)$} & \multicolumn{2}{|c|}{$78.62(2.01)$} & & & & & \\
\hline CR & \multicolumn{2}{|c|}{$39.81(1.97)$} & \multicolumn{2}{|c|}{$62.04(5.27)$} & & & & & \\
\hline B & \multicolumn{2}{|c|}{$25.69(0.84)$} & \multicolumn{2}{|c|}{$54.61(0.95)$} & & & & & \\
\hline GPMTA & \multicolumn{2}{|c|}{$74.94(2.23)$} & \multicolumn{2}{|c|}{$58.71(2.82)$} & & & & & \\
\hline GAMTA & \multicolumn{2}{|c|}{$52.00(4.01)$} & \multicolumn{2}{|c|}{$31.24(6.91)$} & & & & & \\
\hline WPMTA & \multicolumn{2}{|c|}{$93.17(2.53)$} & \multicolumn{2}{|c|}{$91.46(3.91)$} & & & & & \\
\hline WAMTA & \multicolumn{2}{|c|}{$94.93(4.10)$} & \multicolumn{2}{|c|}{$71.04(5.55)$} & & & & & \\
\hline $\mathbf{L}$ & \multicolumn{2}{|c|}{$83.73(2.18)$} & \multicolumn{2}{|c|}{$77.43(9.19)$} & & & & & \\
\hline \multirow[t]{2}{*}{ D } & \multicolumn{2}{|c|}{$72.35(2.12)$} & \multicolumn{2}{|c|}{$95.17(11.07)$} & & & & & \\
\hline & \multicolumn{9}{|c|}{ 3-hour experiment } \\
\hline $\mathbf{C P}$ & $\mathbf{C P}$ & $* *$ & $* *$ & $* *$ & $* *$ & $*$ & $* *$ & & $* *$ \\
\hline CR & & CR & $* *$ & $* *$ & $* *$ & $* *$ & $* *$ & $* *$ & $* *$ \\
\hline B & & & B & $* *$ & $* *$ & $* *$ & $* *$ & $* *$ & $* *$ \\
\hline GPMTA & & & & GPMTA & $* *$ & $* *$ & $* *$ & $* *$ & \\
\hline GAMTA & $\# \#$ & $\#$ & & $\#$ & GAMTA & $* *$ & $* *$ & $* *$ & $* *$ \\
\hline WPMTA & & & & & $\# \#$ & WPMTA & & $* *$ & $* *$ \\
\hline WAMTA & & & & & $\# \#$ & & WAMTA & $* *$ & $* *$ \\
\hline $\mathbf{L}$ & & & & & $\# \#$ & & & $\mathbf{L}$ & $* *$ \\
\hline \multirow[t]{2}{*}{$\mathbf{D}$} & $\# \#$ & \# & & $\# \#$ & $\# \#$ & & & & D \\
\hline & \multicolumn{9}{|c|}{ 24-hour experiment } \\
\hline
\end{tabular}

Statistically significant differences between cell viability of gingival fibroblasts after varied times of exposition of the tested materials: 3-hour experiment: ${ }^{*} p<0.001 ;{ }^{* *} p<0.0001$ and 24 -hour experiment: ${ }^{\#} p<0.05 ;{ }^{* \#} p<0.0001$ based on Tukey's multiple comparisons test.

and Calcipro - a moderate one, and Biopulp was severely cytotoxic. After 24 hours ProRoot and Dycal were non-cytotoxic. Slight cytotoxicity was observed for Angelus White, Calcipulpe, Life, Calcipro, and moderate one for Angelus, ProRoot Regular and Biopulp. After $24 \mathrm{~h}$ of incubation with gingival fibroblasts cultures none of the materials demonstrated severe cytotoxicity.

The differences between cell viability of gingival fibroblasts after various times of exposition to the tested materials are presented in Figure 1. Dycal $(p<0.01)$, Biopulp and Calcipro $(p<0.001)$ significantly increased cell viability after $24 \mathrm{~h}$. The viability of cells was significantly decreased for cells incubated with Calcipulpe, Angelus $(p<0.001)$, Angelus White and ProRoot Regular $(p<0.001)$. There were no significant cell viability differences for ProRoot and Life throughout the entire experiment $(p>0.05)$.
The $\mathrm{pH}$ profile of all the tested materials at 3 and $24 \mathrm{~h}$ is shown in Table 3 . The $\mathrm{pH}$ of non-setting calcium hydroxide materials at $3 \mathrm{~h}$ varied from 11.88 to 11.99 , and at $24 \mathrm{~h}$ from 12.21 to 12.31 . The values for MTA preparations at $3 \mathrm{~h}$ varied from 11.20 to 11.69, and at $24 \mathrm{~h}$ from 11.50 to 11.87 , while the $\mathrm{pH}$ of setting calcium hydroxide materials at $3 \mathrm{~h}$ ranged from 10.15 to 10.47 , and at $24 \mathrm{~h}$ from 10.88 to 11.09 . Statistically significant differences between particular materials are presented in Table 3.

The $\mathrm{pH}$ of all materials tended to significantly increase $(p<0.0001)$ at $24 \mathrm{~h}$ (Fig. 2).

\section{Discussion}

In this study, we evaluated the cytotoxicity and $\mathrm{pH}$ variation of materials used in direct contact with pulp tissue, and provided novel information on some of the 


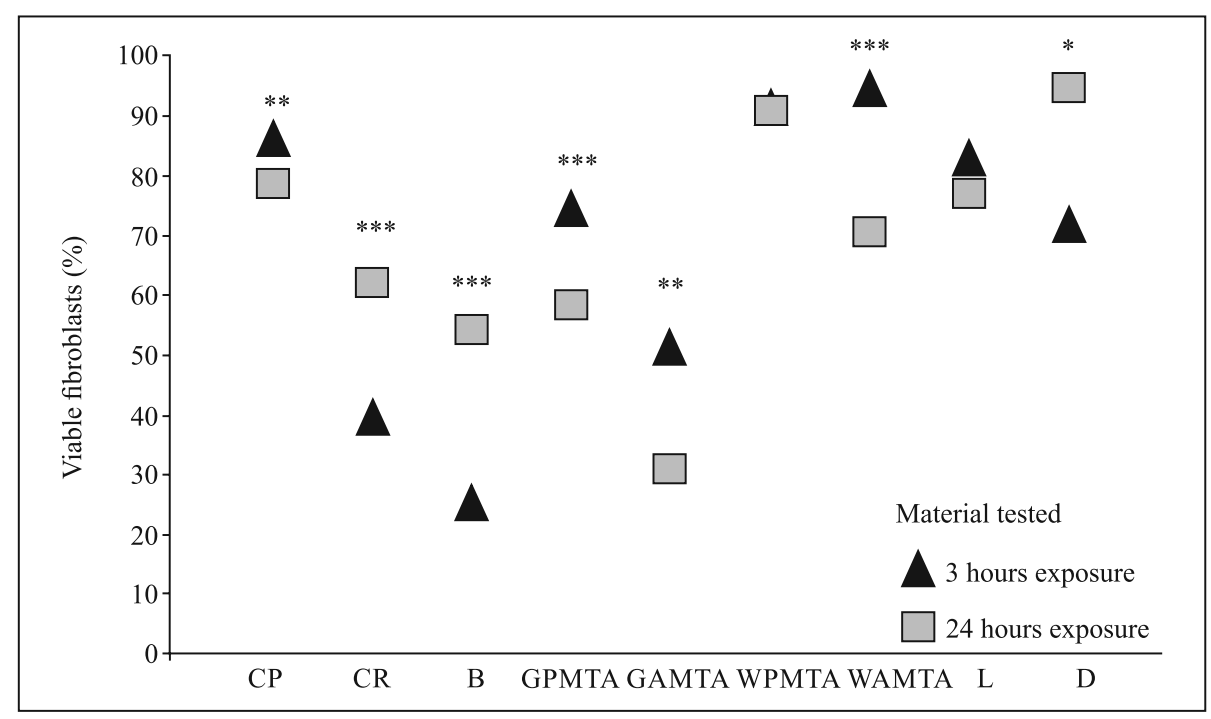

Figure 1. Mean cell viability of human gingival fibroblasts after 3 or 24 hours of exposition to all tested dental capping materials. The statistically significant differences between cell viability of gingival fibroblasts after varied times of exposition for the tested materials as compared to control cells (100\% viability): ${ }^{*} p<0.01{ }^{* *} p<0.001{ }^{* * *} p<0.0001$.

Table 3. Mean and standard deviation $\mathrm{pH}$ values at the two incubation times for all tested materials

\begin{tabular}{|c|c|c|c|c|c|c|c|c|c|}
\hline \multirow[t]{3}{*}{ Material } & \multicolumn{4}{|c|}{ pH (SD) } & & & & & \\
\hline & \multicolumn{4}{|c|}{ Time (h) } & & & & & \\
\hline & \multicolumn{2}{|c|}{3} & \multicolumn{2}{|c|}{24} & & & & & \\
\hline $\mathbf{C P}$ & \multicolumn{2}{|c|}{$11.99(0.06)$} & \multicolumn{2}{|c|}{$12.21(0.03)$} & & & & & \\
\hline CR & \multicolumn{2}{|c|}{$11.89(0.17)$} & \multicolumn{2}{|c|}{$12.31(0.10)$} & & & & & \\
\hline B & \multicolumn{2}{|c|}{$11.88(0.02)$} & \multicolumn{2}{|c|}{$12.25(0.02)$} & & & & & \\
\hline GPMTA & \multicolumn{2}{|c|}{$11.69(0.14)$} & \multicolumn{2}{|c|}{$11.87(0.12)$} & & & & & \\
\hline GAMTA & \multicolumn{2}{|c|}{$11.40(0.17)$} & \multicolumn{2}{|c|}{$11.67(0.12)$} & & & & & \\
\hline WPMTA & \multicolumn{2}{|c|}{$11.58(0.13)$} & \multicolumn{2}{|c|}{$11.76(0.13)$} & & & & & \\
\hline WAMTA & \multicolumn{2}{|c|}{$11.20(0.17)$} & \multicolumn{2}{|c|}{$11.50(0.14)$} & & & & & \\
\hline $\mathbf{L}$ & \multicolumn{2}{|c|}{$10.47(0.22)$} & \multicolumn{2}{|c|}{$11.09(0.12)$} & & & & & \\
\hline \multirow[t]{2}{*}{ D } & \multicolumn{2}{|c|}{$10.15(0.30)$} & \multicolumn{2}{|c|}{$10.88(0.23)$} & & & & & \\
\hline & \multicolumn{9}{|c|}{ 3-hour experiment } \\
\hline $\mathbf{C P}$ & $\mathbf{C P}$ & & & & $* * * *$ & $*$ & $* * * *$ & $* * * *$ & $* * * *$ \\
\hline CR & & CR & & & $* * *$ & & $* * * *$ & $* * * *$ & $* * * *$ \\
\hline B & & & B & & $* *$ & & $* * * *$ & $* * * *$ & $* * * *$ \\
\hline GPMTA & \# & $\# \#$ & $\# \#$ & GPMTA & $* * * *$ & & $* * *$ & $* * * *$ & $* * * *$ \\
\hline GAMTA & \#\#\# & $\# \#$ & $\# \#$ & & GAMTA & & & $* * * *$ & $* * * *$ \\
\hline WPMTA & $\# \#$ & $\# \# \#$ & $\# \# \#$ & & & WPMTA & $*$ & $* * * *$ & $* * * *$ \\
\hline WAMTA & $\# \#$ & $\# \#$ & $\# \#$ & $\# \#$ & & & WAMTA & $* * * *$ & $* * * *$ \\
\hline $\mathbf{L}$ & $\# \#$ & $\# \#$ & $\# \#$ & $\# \#$ & $\# \#$ & $\# \#$ & $\# \#$ & $\mathbf{L}$ & \\
\hline \multirow[t]{2}{*}{ D } & $\# \#$ & $\# \#$ & $\# \#$ & $\# \#$ & $\# \#$ & $\# \#$ & $\# \#$ & & D \\
\hline & \multicolumn{9}{|c|}{ 24-hour experiment } \\
\hline
\end{tabular}

Statistically significant differences of $\mathrm{pH}$ values between particular materials in the 3 -hour experiment: $*_{p}<0.05 ; * * p<0.01 ; * * * p<0.001 ; * * * * p<0.0001$ and 24-hour experiment: ${ }^{\#} p<0.05 ;{ }^{\#} p<0.001 ;{ }^{\# \#} p<0.0001$ based on Tukey's multiple comparisons test. 


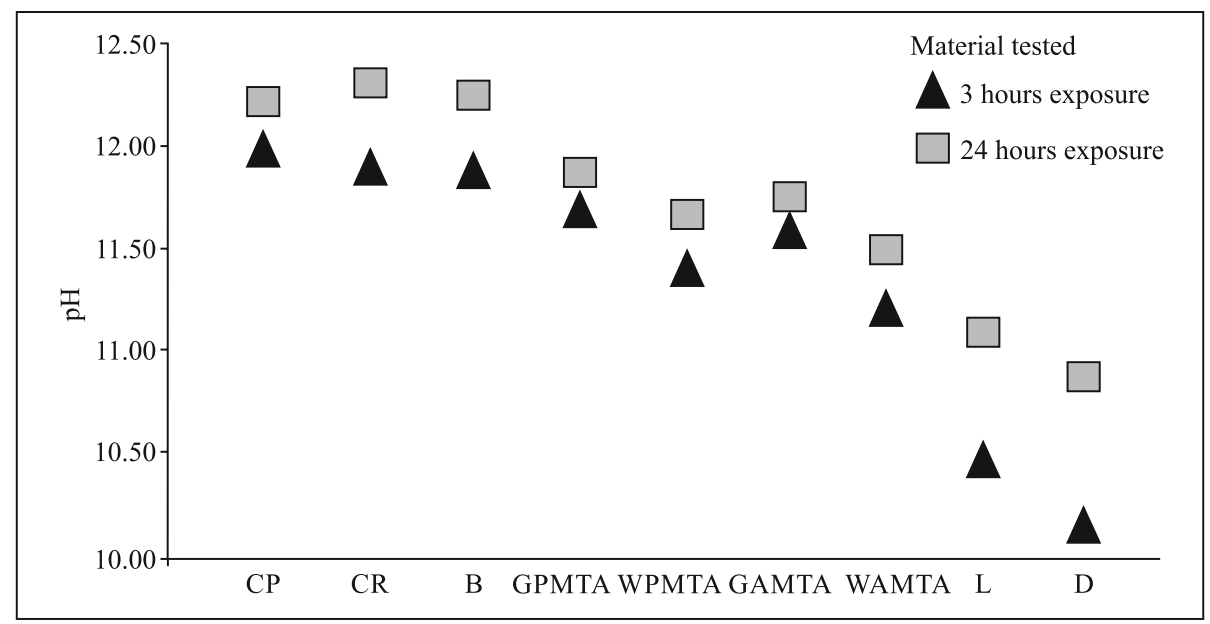

Figure 2. Mean $\mathrm{pH}$ values after 3 or 24 hours of exposition to all tested dental capping materials. The differences were statistically significant at $p<0.001$ between all tested materials as compared to deionized water (control) after 3 and 24 hours of exposure.

biological and chemical properties of these materials. Cell culture studies of dental materials have shown previously that cell response to the material depends on various factors such as cell line and experimental period, material state, the use of inserts or material extracts $[1,2,5]$.

Various methods, in vitro and in vivo, are described for the evaluation of the dental materials' biocompatibility. The in vitro methods are simple, rapid, reproducible and cost-effective. The established cell lines, which were used in this experiment, are more sensitive and provide more reproducible results than primary cell cultures $[17,18]$. The possibility of introducing experimental variations of the in vitro test systems allows evaluating the cytotoxicity of dental materials. The assay adapted in the present study used the tetrazolium salt MTT to measure mitochondrial dehydrogenase activity. There are no uniform standards for cytotoxicity assays on cell cultures. We used the insert system for testing the effects of the capping materials since they are applied in the cells' medium without interfering directly with the cells which resembles the in vivo situation.

Our research scheme largely reflects clinical conditions. The materials were tested as freshly mixed materials at two different exposure times -3 and $24 \mathrm{~h}$ - to observe their effects on cell survival. Most of the studies concern materials after setting $[1,7-9,19$, 20]. Only Keiser et al. evaluated the cytotoxicity of freshly mixed and set grey experimental MTA after $24 \mathrm{~h}$ of exposure to the two varying concentrations. They observed that the lower tested concentration resulted in increased cell viability than the higher one [21].
In the current study, we showed differences in cell viability of gingival fibroblasts after varied times of exposition ( 3 and $24 \mathrm{~h}$ ) to the tested materials. Cell viability after $24 \mathrm{~h}$ significantly increased for Dycal, Biopulp and Calcipro, and significantly decreased for Calcipulpe, Angelus, Angelus White and ProRoot Regular. Cell viability for ProRoot and Life remained statistically equivalent throughout the entire experiment.

From non-setting calcium hydroxide materials, only Calcipulpe showed an increase in cytotoxicity over time. The other two materials, Biopulp and Calcipro, significantly reduced cytotoxicity. Unlike Calcipulpe, the latter two materials require being mixed just before use, which may result in difficulties maintaining accurate proportions and may affect the discussed parameter. Although similar in composition, setting calcium hydroxide materials had varied effects. After 24 h of observation, Life reduced cell viability in culture, while Dycal significantly increased it. This might have been caused by different components of both materials (Table 1 ).

MTA is available as gray and white. Not only do the two differ in composition, but some studies have shown differences in their properties [22, 23]. There is no consensus among authors in relation to the cytotoxicity of white and gray MTA. According to Al Anezi et al. [22] there were no differences in cytotoxicity between gray and white ProRoot. In our experiment, we demonstrated significant differences between two kinds of MTA, at 3 and $24 \mathrm{~h}$. Gray forms of MTA demonstrated significantly greater cytotoxicity than white ones at both experimental periods. This is presumably caused by increased content of 
arsenic in gray MTA, as was confirmed by Bramante et al. [23]. Arsenic is well known as an inhibiting factor of enzyme activity, also of succinate dehydrogenase which was assessed in the MTT test.

The $\mathrm{pH}$ range of a material is an essential physical attribute, which is associated with pulpal response [24]. All testing materials used in our study had alkaline $\mathrm{pH}$. Based on the obtained results, the tested materials were divided into 3 groups in terms of their $\mathrm{pH}$ value. The highest $\mathrm{pH}$ was produced by non-setting calcium hydroxide preparations followed by the MTA group and setting calcium hydroxide materials. Numerous investigations referring to pulp capping material $\mathrm{pH}$ are available in the literature. However, there are no studies comparing non-setting and setting calcium hydroxide materials and also MTA cements in a single experiment. Authors using a similar methodology to ours observed the greatest release of $\mathrm{OH}$ ions from non-setting calcium hydroxide materials [25], which is confirmed by our results. The fast alkalizing effects of these materials is due to the direct contact of the calcium hydroxide with the environment, leading to instantaneous immediate release of hydroxyl ions [25]. On the other hand, setting materials are consisted of two pastes, which following curing process produce calcium-alkyl-salicylate chelate. Hydroxyl ions are chemically bound and are incapable to be released immediately after application [26].

The release of calcium and hydroxyl ions is the result of the formation of calcium hydroxide in materials on the basis of MTA [27]. In the present study, four MTA cements still released hydroxyl ions and maintained elevated $\mathrm{pH}$, which corroborate the findings of other authors [28, 29].

Under the conditions of our study, final conclusions cannot be formulated. Currently used pulp capping materials varied in their cytotoxicity relative to human gingival fibroblast and their alkalizing abilities. Since most likely $\mathrm{pH}$ does not affect the viability of cultured cells, further investigations are required to determine physicochemical properties of these materials and the biological activity of the dental pulp.

\section{Conflict of interest}

The authors deny any conflicts of interest.

\section{References}

1. Takita T, Hayashi M, Takeichi O, et al. Effect of mineral trioxide aggregate on proliferation of cultured human dental pulp cells. Int Endod J. 2006; 39(5): 415-422, doi: 10.1111/j.13652591.2006.01097.x, indexed in Pubmed: 16640642.

2. Camargo SEA, Camargo CHR, Hiller KA, et al. Cytotoxicity and genotoxicity of pulp capping materials in two cell lines. Int Endod J. 2009; 42(3): 227-237, doi: 10.1111/j.13652591.2008.01506.x, indexed in Pubmed: 19228213.
3. Tziafas D. The future role of a molecular approach to pulp-dentinal regeneration. Caries Res. 2004; 38(3):314-320, doi: 10.1159/000077771, indexed in Pubmed: 15153705.

4. Dominguez MS, Witherspoon DE, Gutmann JL, et al. Histological and scanning electron microscopy assessment of various vital pulp-therapy materials. J Endod. 2003; 29(5): 324-333, doi: 10.1097/00004770-200305000-00003, indexed in Pubmed: 12775004.

5. Camilleri J, Pitt Ford TR. Mineral trioxide aggregate: a review of the constituents and biological properties of the material. Int Endod J. 2006; 39(10): 747-754, doi: 10.1111/j.13652591.2006.01135.x, indexed in Pubmed: 16948659.

6. Schuurs AH, Gruythuysen RJ, Wesselink PR. Pulp capping with adhesive resin-based composite vs. calcium hydroxide: a review. Endod Dent Traumatol. 2000; 16(6): 240-250, indexed in Pubmed: 11202889.

7. Khashaba RM, Lockwood PE, Lewis JB, et al. Cytotoxicity, calcium release, and $\mathrm{pH}$ changes generated by novel calcium phosphate cement formulations. J Biomed Mater Res B Appl Biomater. 2010; 93(2): 297-303, doi: 10.1002/jbm.b.31494, indexed in Pubmed: 20235188.

8. Hirschman WR, Wheater MA, Bringas JS, et al. Cytotoxicity comparison of three current direct pulp-capping agents with a new bioceramic root repair putty. J Endod. 2012; 38(3): 385-388, doi: 10.1016/j.joen.2011.11.012, indexed in Pubmed: 22341080.

9. Ko H, Yang W, Park K, et al. Cytotoxicity of mineral trioxide aggregate (MTA) and bone morphogenetic protein 2 (BMP-2) and response of rat pulp to MTA and BMP-2. Oral Surg Oral Med Oral Pathol Oral Radiol Endod. 2010; 109(6): e103-e108, doi: 10.1016/j.tripleo.2010.01.030, indexed in Pubmed: 20451825.

10. Margunato S, Taşlı PN, Aydın S, et al. In Vitro Evaluation of ProRoot MTA, Biodentine, and MM-MTA on Human Alveolar Bone Marrow Stem Cells in Terms of Biocompatibility and Mineralization. J Endod. 2015; 41(10): 1646-1652, doi: 10.1016/j.joen.2015.05.012, indexed in Pubmed: 26410417.

11. Silva EJ, Neves AA, De-Deus G, et al. Cytotoxicity and gelatinolytic activity of a new silicon-based endodontic sealer. J Appl Biomater Funct Mater. 2015; 13(4): e376-e380, doi: 10.5301/jabfm.5000238, indexed in Pubmed: 26391870.

12. Silva EJ, Santos CC, Zaia AA. Long-term cytotoxic effects of contemporary root canal sealers. J Appl Oral Sci. 2013; 21(1): 43-47, doi: 10.1590/1678-7757201302304, indexed in Pubmed: 23559111.

13. Mohammadi Z, Dummer PMH. Properties and applications of calcium hydroxide in endodontics and dental traumatology. Int Endod J. 2011; 44(8): 697-730, doi: 10.1111/j.13652591.2011.01886.x, indexed in Pubmed: 21535021.

14. Okabe T, Sakamoto M, Takeuchi H, et al. Effects of $\mathrm{pH}$ on mineralization ability of human dental pulp cells. J Endod. 2006; 32(3): 198-201, doi: 10.1016/j.joen.2005.10.041, indexed in Pubmed: 16500225.

15. de Andrade Ferreira FB, Silva E Souza Pd, do Vale MS, et al. Evaluation of $\mathrm{pH}$ levels and calcium ion release in various calcium hydroxide endodontic dressings. Oral Surg Oral Med Oral Pathol Oral Radiol Endod. 2004; 97(3): 388-392, doi: 10.1016/S1079210403005237, indexed in Pubmed: 15024365 .

16. Bae KH, Chang SW, Bae KS, et al. Evaluation of $\mathrm{pH}$ and calcium ion release in capseal I and II and in two other root canal sealers. Oral Surg Oral Med Oral Pathol Oral Radiol Endod. 2011; 112(5): e23-e28, doi: 10.1016/j.tripleo.2011.04.031, indexed in Pubmed: 21872513. 
17. Murray PE, Garcia Godoy C, Garcia Godoy F. How is the biocompatibility of dental biomaterials evaluated? Medicina Oral Patologia y Oral Cirugia Bucal. 2007; 12(3): E258-E266, indexed in Pubmed: 17468726.

18. Wataha JC. Principles of biocompatibility for dental practitioners. J Prosthet Dent. 2001; 86(2): 203-209, doi: 10.1067/ mpr.2001.117056, indexed in Pubmed: 11514810.

19. Camilleri J, Montesin FE, Di Silvio L, et al. The chemical constitution and biocompatibility of accelerated Portland cement for endodontic use. Int Endod J. 2005; 38(11): 834-842, doi: 10.1111/j.1365-2591.2005.01028.x, indexed in $\mathrm{Pu}-$ bmed: 16218977.

20. Yoshino P, Nishiyama CK, Modena KC, et al. In vitro cytotoxicity of white MTA, MTA Fillapex ${ }^{\circledR}$ and Portland cement on human periodontal ligament fibroblasts. Braz Dent J. 2013; 24(2): 111-116, doi: 10.1590/0103-6440201302115, indexed in Pubmed: 23780362.

21. Keiser K, Johnson CC, Tipton DA. Cytotoxicity of mineral trioxide aggregate using human periodontal ligament fibroblasts. J Endod. 2000; 26(5): 288-291, doi: 10.1097/00004770200005000-00010, indexed in Pubmed: 11199738.

22. AlAnezi A, Jiang J, Safavi K, et al. Cytotoxicity evaluation of endosequence root repair material. Oral Surg Oral Med Oral Pathol Oral Radiol Endod. 2010; 109(3): e122-e125, doi: 10.1016/j.tripleo.2009.11.028.

23. Monteiro Bramante C, Demarchi AC, de Moraes IG, et al. Presence of arsenic in different types of MTA and white and gray Portland cement. Oral Surg Oral Med Oral Pathol
Oral Radiol Endod. 2008; 106(6): 909-913, doi: 10.1016/j.tripleo.2008.07.018, indexed in Pubmed: 18835535.

24. Hirose Y, Yamaguchi M, Kawabata S, et al. Effects of extracellular pH on dental pulp cells in vitro. J Endod. 2016; 42(5): 735-741, doi: 10.1016/j.joen.2016.01.019, indexed in Pubmed: 26951958.

25. Zmener O, Pameijer CH, Banegas G. An in vitro study of the $\mathrm{pH}$ of three calcium hydroxide dressing materials. Dent Traumatol. 2007; 23(1): 21-25, doi: 10.1111/j.16009657.2005.00447.x, indexed in Pubmed: 17227376.

26. Tamburić SD, Vuleta GM, Ognjanović JM. In vitro release of calcium and hydroxyl ions from two types of calcium hydroxide preparation. Int Endod J. 1993; 26(2): 125-130, doi: 10.1111/ j.1365-2591.1993.tb00554.x, indexed in Pubmed: 8330935.

27. Tanomaru-Filho M, Chaves Faleiros FB, Saçaki JN, et al. Evaluation of $\mathrm{pH}$ and calcium ion release of root-end filling materials containing calcium hydroxide or mineral trioxide aggregate. J Endod. 2009; 35(10): 1418-1421, doi: 10.1016/j. joen.2009.07.009, indexed in Pubmed: 19801243.

28. Duarte MA, Demarchi AC, Yamashita JC, et al. pH and calcium ion release of 2 root-end filling materials. Oral Surg Oral Med Oral Pathol Oral Radiol Endod. 2003; 95(3): 345-347, doi: 10.1067/moe.2003.12, indexed in Pubmed: 12627108.

29. Antunes Bortoluzzi E, Juárez Broon N, Antonio Hungaro Duarte M, et al. The use of a setting accelerator and its effect on $\mathrm{pH}$ and calcium ion release of mineral trioxide aggregate and white Portland cement. J Endod. 2006; 32(12): 1194-1197, doi: 10.1016/j.joen.2006.07.018, indexed in Pubmed: 17174682.

Submitted: 13 December, 2016

Accepted after reviews: 12 May, 2017

Available as AoP: 18 May, 2017 
